DE DE GRUYTER

OPEN

G

Maciej Dębski

University of Social Sciences
Journal of Intercultural Management

Vol. 6, No. 1, January 2014 , pp. 67-79

DOI 10.2478/joim-2014-0005

Kinga Niemczak

University of Applied Sciences Wiener Neustad

\title{
The image of Germany in Poland and its impact on development of Poles travelling tourism to Germany
}

\begin{abstract}
The country image tends to be a crucial element for supporting national products on foreign markets. This is also a case for tourist products. The Germany brand is one of the most powerful brands across the world. However, it seems, as highlighted in the research hypothesis, that in the case of tourism its impact on the Poles is not as strong as in the case of numerous other economic spheres. The poll research conducted on a selected group of respondents revealed the grounds for the hypothesis stated. Respondents evaluated relatively poorly both the attractiveness of Germany as well as their urge to visit that country compared to other European countries, they also rated poorly the selected highlights of the country. Another barrier related to perceived attractiveness of Germany is a not entirely positive stereotype of German people. The results reveal the need for changes of it, which are possible in the light of better ratings given by persons who previously visited Germany.
\end{abstract}

Key words: tourism, image, Germany, attractiveness, country of origin effect

\section{Introduction}

In present day economy competition takes place on a number of levels: products, enterprises or countries. They compete for inflow of investments, tourists and the highest possible sale of products originating from these countries. The perception or the image of the given country is a powerful source of competitive advantage on all listed levels, affecting the competitiveness of 
the economy, also during crisis. The surveys over these issues carried out in various countries corroborate the relationship between the country perception and products originating from that country. The reference literature defines this interdependence as „country-of-origin effect”.

The country image or brand proves to be a significant driver likely to act as a stimulant as well as barrier to the development of tourism because the country perception guides many decisions on travelling in international tourism. Though it should be kept in mind that the country image is a very complex construct which is, first, influenced by various factors such as: economy, sport, history, people or natural circumstances, second, the country image has different implications for specific products, for instance, an origin of a product from France will certainly have a positive impact on cosmetics, whereas in the case of cutting-edge technologies, it will produce contrary effects. Yet for such products, an origin from Japan is an undisputable asset, though a clearly positive image of the country fails to be beneficial for the clothing industry.

The Germany brand is one of the most powerful national brands, rated the $7^{\text {th }}$ in the rating of the brands in 2012 [Smith J., 2012]. Clearly, in most cases the origin of a product from that country constitutes a crucial added value contributing to an enhanced evaluation. Nevertheless, it seems expedient to raise a question on whether this is the case for the tourist products which evaluation frequently differs from the evaluation of other products originating from specific countries. Therefore the major research question addressed in the study will be as follows: in which way the German image influences the Polish market in terms of tourist products. It appears that the added value created by the country image for the group of products discussed is lower than for numerous other consumption products. Thus the major hypothesis of the study is as follows: in the case of tourist products a tremendously positive impact of the German brand on Polish consumers is not reported which is an essential factor curbing the travel of Poles to Germany. Accordingly, the poll research on a selected sample of young Poles was conducted so as to verify the above hypothesis.

The focus on the specified research area is justified because the Federal Republic of Germany is the country most visited by the Poles according to the data provided by the Tourism Institute in 2011 [Wyjazdy...]. Such a situation is, to a large extent, the result of close geographical proximity. Also, the attractiveness and well-developed infrastructure play a substantial role as well. Though, it is worth examining the implications of the perception of Germany in Poland for travelling decisions among Poles, in terms of both stimulants and hindrances. 


\section{Country image - competitive factor for products originating from it}

While expanding globalization processes, the image of the country of origin of both the brand and the product became an essential element of competitiveness. It should positively influence, among others: perception of brands and products originating from that country. The reference literature labels such correlations as country-of-origin effect which may be defined as "picture, the reputation, the stereotype that businessmen and consumers attach to products of a specific country" [Li D., Ahn J., Zhou R., Wu B, 2009, p. 623]. As emphasized by Sipos and Nefzger, this effect exerts mighty influence on the perception of the quality of the products manufactured in a given country [2011, p. 2]. Whereas P. Verlegh argues that the country of origin plays the role of the specific mental shortcuts facilitating the product evaluation, especially when it is not widely known and information about it is insufficient [2010. p. 49].

The literature of the subject does not challenge the occurrence of the phenomenon. However, as demonstrated by Herz and Diamantopoulos, despite numerous studies investigating the country-of-origin effect, there is no consensus on its implications and strength of its impact among scholars [2013, p. 410]. It should be stressed that the phenomenon is often divided by specifying the brand origin and the country of manufacture [Hamzaoui-Essoussi L., Merinka D., Bartikowski B., 2011, p. 973]. Various studies emphasize that the impact and significance of the country is contingent on the type of the product, e.g. the country of origin is less important for the products characterized by a high degree of standardization.

It has been suggested that the issues of the country image or its brand as well as its management may be examined from three perspectives. First, countries may build their image as a tourism destination. Second, countries may create an image as an attractive location for foreign direct investments, and third, they may strive to develop their image as a manufacturer of high quality products (this approach prevails in research and literature) [Pappu R., Quester P., 2010, p. 277].

A country image is undoubtedly a significant element driving the evaluation of products originating from that country, including tourism products. As claimed by Seth the fact that the country enjoys a wide variety of natural attractions and anthropogenic sites does not necessarily imply a massive inflow of tourists. This is contingent on the country image predominant in the states from which tourists come. India is a good example. Certainly, this country offers abundant attractions, yet it fails to attract as many tourists as tiny Singapore. Although people are aware of the rich resources possessed by India, they view that country from the perspective of poverty, poor hygiene or lack of safety. Such an image is a mighty barrier constraining tourist travels [Seth P., 2008, p. 18]. 
A country image is a construct much more complex than traditional products, this is a derivative of a far larger number of factors. The country perception is determined by, among others, history, entertainment industry, media, arts, music, famous figures, enterprises, language or commercial brand products [Skinner H., Kubacki K., Moss G., Chelly D., 2008, pp. 193-215].

It is easily noticed that these factors are characterized by great diversity, not all may be subject to active management. However, it should be agreed that it is crucial to monitor the country image and, above all, the image should be shaped, managed with the goal, as described by Fetscherin, of creating positive international perception, and consequently a positive approach towards the country [2010, p. 468], which should result in a positive effect on products, including tourism products originating from that country.

Figure 1. Structure of tourism products

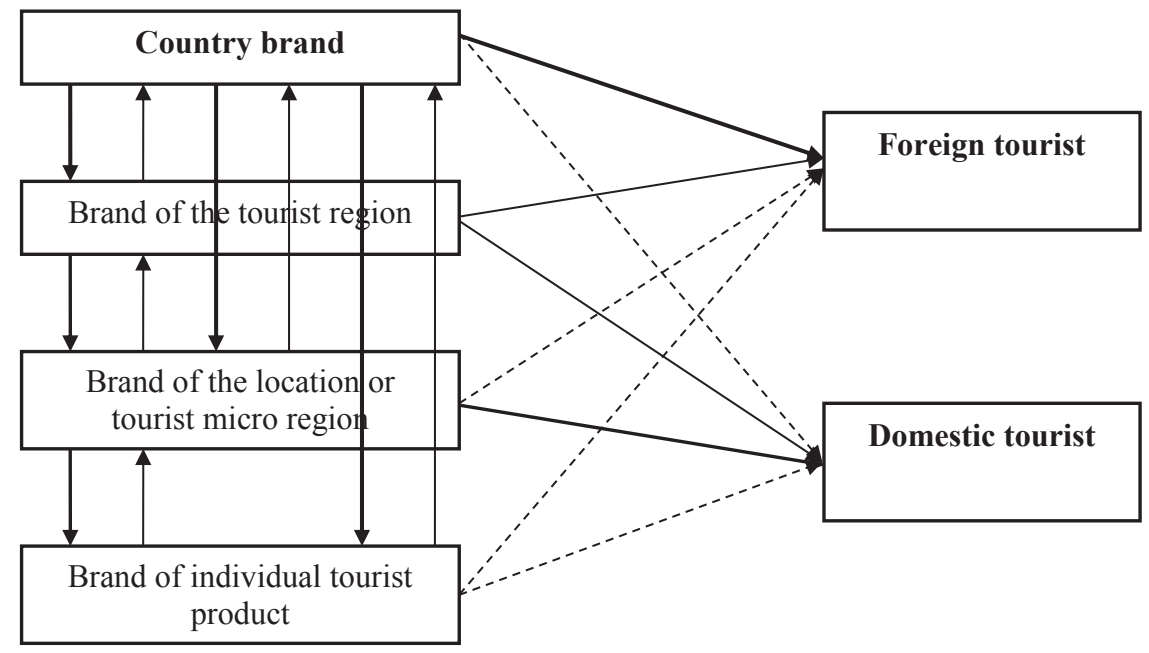

Source: Dębski M., 2012, p. 29

According to the model outlined in Figure 1 there are a number of interactions occurring between the country brands and destinations located there. Though central to the investigations conducted is the issue of the impact made by specific brands. The country brand and its image have the critical influence on the decisions made by buyers - tourists with regard to travelling abroad. In consequence a primary research question to be addressed is: what is the German image as an area for tourist reception in Poland? 


\section{German image as a tourism destination - methodology and research hypothesis}

is among the largest and most affluent European states enjoying rich history and fairly diversified landscape. Therefore, the thesis on its tremendous appeal appears to be entirely validated. As presented in the report produced by the European Travel Commission in 2013 there was a significant surge in travellers to Germany compared to the previous year [European..., 2013, p. 1]. Equally, this is a country mostly perceived (particularly in Poland) in the context of the contemporary history and its economy. It is hence reasonable to embark on a discussion about its perception in the light of its tourist attractiveness. It seems that its tourism potentials may be underrated to some extent due to persistent stereotypes about Germany and Germans. Basically, lingering associations may effectively decrease the attractiveness of the country in the perception of potential tourists.

Accordingly, it is legitimate to offer the following hypothesis previously specified: in the context of tourism products there is no particularly positive impact of the Germany brand on Polish consumers, which may serve as a factor limiting travels of Poles to Germany. Verification of the foregoing hypothesis entails the response to the question: how the Poles perceive Germans and Germany and what impact it has on travelling activities of Poles to that country.

The survey conducted in May-June 2013 was designed to verify the hypothesis made and to search for the answer to the question raised. The survey comprised two phases. The first phase involved completing the survey questionnaire by a group of students from a Warsaw higher education institution. The questionnaire mostly included open-ended questions related to the perception of Germany, Germans and familiarity with tourist attractions in Germany. The key questions were as follows:

- What associations do you have with Germany?

- What association, what features do you associate with the Germans?

- What tourist attractions do you know in Germany?

This was the pilot stage and the responses received were used to prepare a proper survey questionnaire dominated by closed-ended questions. The selection? was established based on the most frequent responses to questions raised at the phase $\mathrm{I}$.

The phase II sought to collect 200 appropriately completed questionnaires, and following their verification 197 answers were used for the formulation of the findings. The respondents were selected among students of Warsaw higher education institutions. Such selection was guided by the belief that the group included young residents of Warsaw, and it was an intentional move because young persons characterise with high tourist activity, and furthermore persons 
aged 20-30 are the second generation born after the WW2 which makes them less burdened with its negative connotations. These assumptions were corroborated in the survey: residents of cities over 100,000 inhabitants represented $47 \%$ of participants, and persons below 25 years $-55 \%$ of the respondents. It should be also highlighted that $31 \%$ of respondents were persons who visited Germany as adults. This information is crucial because when answering the questions these persons rely on their experiences, not merely on the perception.

The sample was not a representative selection which causes that the results obtained should be approached in a judgemental manner. Meanwhile the results received lead to various intriguing conclusions likely to be an interesting basis for further discussions.

\section{German image in Poland and its impact on the development of tourism - survey findings}

The first question of the survey accomplished was intended to verify the significance of the country brand in tourism. According to the model displayed previously (Fig. 1) the country image tends to be critical for the foreign tourism. The respondents were asked to indicate the place where they spent their holidays abroad, $37 \%$ of them failed to provide responses to the above question or they said they did not spend holidays abroad. Yet the answers given by the remaining $63 \%$ are distinctive. $54 \%$ of those indicating the location of their holidays specified the country or the country name in the location description. Only $9 \%$ pointed out the city or region. The outcome explicitly suggests that the country brand prevails in the perception of the holiday destination among the respondents. Hence it may be assumed that it will also be a critical factor driving the travelling decisions. As a result, in line with the model illustrated, an emphasis should be placed on the country brand when promoting the country on foreign markets as a destination.

After all, it is advisable to discuss how Germany is perceived as a tourism destination compared to other European countries. The results obtained from the survey on the above issue were detailed in Table 1 . The countries that topped the ranking included: Italy, Spain and Greece. Traditionally, these are the countries occupying a remarkably high position in Polish travelling tourism. Whereas a rate of 2.79 put Germany low in the rating among the worst evaluated countries (solely countries emerging in the aftermath of the collapse of the Soviet Union received worse rating). Slightly better rating was given by persons who previously visited Germany -2.96 but such rating is still poor. The findings presented clearly should not be estimated positively and they clearly show that Germany is not viewed as an attractive tourism destination. Importantly, they also provide grounds for the formulation of the statement that a mighty German brand underpinning numerous products fails to support tourism. 
Table 1. Evaluation of tourist attractiveness of selected European states

\begin{tabular}{|l|l|l|l|l|l|l|}
\hline Country & Rating & Country & Rating & Country & Rating \\
\hline Italy & 4,37 & France & 3.96 & Lithuania & 2.46 \\
\hline Spain & 4.5 & Slovakia & 2.85 & Holland & 3.18 \\
\hline Russia & 2.64 & Germany & 2.79 & Portugal & 3.95 & \\
\hline Greece & 4.02 & Great Britain & 3.45 & Ukraine & 2.46 & \\
\hline $\begin{array}{l}\text { Czech Re- } \\
\text { public }\end{array}$ & 2.86 & Norway & 3.3 & \multicolumn{2}{|l|}{$\begin{array}{l}\text { Germany - persons previ- } \\
\text { ously visiting that country }\end{array}$} & 2.96 \\
\hline
\end{tabular}

Source: Own study based on the research conducted

Notice: Respondents evaluated attractiveness in the scale 1-5

Large and recognizable cities are of a tremendous significance for expanding tourism and building the image of the country as a tourism destination, particularly on the European market. Table 2 shows the respondents' responses evaluating the attractiveness of German cities as compared to other European cities. Similarly, as in the previous evaluation, German cities were not highly rated, though the average rating for Munich and Berlin tends to outperform the rating of the country as a whole. It should be underlined that, as in the previous case, persons previously visiting the country gave higher ratings to the German cities.

Table 2 Evaluation of tourist attractiveness of selected European cities

\begin{tabular}{|l|l|l|l|l|l|}
\hline City & Rating & City & Rating & City & Rating \\
\hline Paris & 4.36 & Berlin & $3.38(3.38)$ & Milan & 3.96 \\
\hline Munich & $3.5(3.6)$ & Rome & 4.57 & Barcelona & 4.32 \\
\hline Turin & 3.4 & Moscow & 3.29 & Kiev & 2.88 \\
\hline Budapest & 3.47 & Frankfurt & $2.96(3.22)$ & London & 3.77 \\
\hline Vilnius & 3.27 & Venetia & 4.26 & Hamburg & $2.93(3.11)$ \\
\hline
\end{tabular}

Source: Own study based on the research conducted

Notice: Respondents evaluated attractiveness in the scale 1-5, the brackets show the attractiveness evaluation of German cities made by persons who previously visited Germany.

The analysis of the first batch of findings seems to lead to two conclusions. First, Germany as well as German cities are not rated highly as tourism destinations. Thus the Germany brand fails to support German tourism products as is the case for other products. Furthermore, a higher rating to the Germany attractiveness given by persons having visited the country implies that stereotypes lingering in Poland are less favourable than the evaluation of the reality made by visitors. Such a situation evidently reveals the urgency of initiatives aimed at improving the perception of Germany in Poland as an attractive destination. 
At the heart of each image are associations invoked by the product and its brand, the German brand in the discussed case. The key products were featured in Table 3. The most indications were received by: good motorways, Volkswagen, Merkel, war or superior cars. One may easily notice that they are not, except for war, negative associations and at the same time they are not directly related to tourism or perception of tourist attractiveness of the country.

Table 3. Associations for the federal Republic of Germany

\begin{tabular}{|l|l|l|l|l|l|}
\hline Association & $\begin{array}{l}\text { Indication } \\
\text { (all) }\end{array}$ & $\begin{array}{l}\text { Indication } \\
\text { those having } \\
\text { visited Ger- } \\
\text { many) }\end{array}$ & Association & $\begin{array}{l}\text { Indication } \\
\text { (all) }\end{array}$ & $\begin{array}{l}\text { Indication } \\
\text { those having } \\
\text { visited Ger- } \\
\text { many) }\end{array}$ \\
\hline Bavaria & $63 \%$ & $79 \%$ & Sea & $5 \%$ & $8 \%$ \\
\hline Safe & $19 \%$ & $26 \%$ & Merkel & $60 \%$ & $73 \%$ \\
\hline $\begin{array}{l}\text { They do not } \\
\text { like Poles }\end{array}$ & $45 \%$ & $42 \%$ & $\begin{array}{l}\text { It is worth buy- } \\
\text { ing its products }\end{array}$ & $39 \%$ & $39 \%$ \\
\hline Beer & $67 \%$ & $81 \%$ & $\begin{array}{l}\text { Attractive } \\
\text { cities }\end{array}$ & $11 \%$ & $18 \%$ \\
\hline $\begin{array}{l}\text { High standard } \\
\text { of living }\end{array}$ & $56 \%$ & $56 \%$ & $\begin{array}{l}\text { Interesting } \\
\text { country }\end{array}$ & $13 \%$ & $21 \%$ \\
\hline Expensive & $25 \%$ & $31 \%$ & Volkswagen & $68 \%$ & $68 \%$ \\
\hline $\begin{array}{l}\text { Good motor- } \\
\text { ways }\end{array}$ & $83 \%$ & $83 \%$ & Football & $52 \%$ & $53 \%$ \\
\hline War & $63 \%$ & $63 \%$ & Mountains & $4 \%$ & $11 \%$ \\
\hline $\begin{array}{l}\text { Monuments, } \\
\text { museums }\end{array}$ & $10 \%$ & $16 \%$ & Ugly language & $59 \%$ & $60 \%$ \\
\hline Saxony & $17 \%$ & $17 \%$ & Good cars & $63 \%$ & $68 \%$ \\
\hline
\end{tabular}

Source: Own study based on the research conducted

Notice: Respondents evaluated attractiveness in the scale 1-5,cafeteria of responses was prepared based on the findings obtained from the first phase of the survey during which a selected group of respondents presented associations for Germany in open-ended question, associations referring to tourism were bolded.

One of the objectives of examining the associations for Germany was to verify the development of associations linked to tourism among varied associations. These associations were made bold in Table 3. It may be easily traced that among diverse elements of the image of the Germany brand they received the least indications. Such results certainly provide grounds for adopting the statement that Germany is not viewed as an attractive destination. This evaluation is not alleviated by the fact that among all cases a higher percentage of indications was given by persons previously visiting Germany. The difference in evaluation by two groups is substantial, though the percentage of persons associating Germany with tourist highlights remains relatively low. 
The evaluation of tourist attractiveness of Germany and the urge to visit the country for tourist purposes is of significant importance. The subsequent questions of the survey concerned with the foregoing issues, and collective results from the responses were presented in Table 4.

Table 4. Evaluation of attractiveness and willingness to visit Germany

\begin{tabular}{|l|l|l|l|l|l|}
\hline Would you like to visit Germany for tourist purposes? \\
\hline Response & $\begin{array}{l}\text { Yes - very } \\
\text { much }\end{array}$ & Rather yes & Rather no & Definitely no & No opinion \\
\hline $\begin{array}{l}\text { Percentage of indica- } \\
\text { tions (respondents } \\
\text { in total) }\end{array}$ & $6 \%$ & $36 \%$ & $35 \%$ & $8 \%$ & $15 \%$ \\
\hline $\begin{array}{l}\text { Percentage of in- } \\
\text { dications (those } \\
\text { previously visiting } \\
\text { Germany) }\end{array}$ & $10 \%$ & $40 \%$ & $32 \%$ & $8 \%$ & $10 \%$ \\
\hline Do you consider Germany as an attractive tourism destination? & $3 \%$ & $24 \%$ \\
\hline $\begin{array}{l}\text { Percentage of indica- } \\
\text { tions (respondents } \\
\text { in total) }\end{array}$ & $2 \%$ & $39 \%$ & $32 \%$ & $3 \%$ & $21 \%$ \\
\hline $\begin{array}{l}\text { Percentage of in- } \\
\text { dications (those } \\
\text { previously visiting } \\
\text { Germany) }\end{array}$ & $5 \%$ & $45 \%$ & $23 \%$ & $5 \%$ & \\
\hline
\end{tabular}

Source: Own study based on the research conducted

The present findings are consistent with previous observations and reveal that Germany is viewed rather neutrally in terms of tourist attractiveness, which means that the percentage of respondents perceiving the country as an attractive tourist destination is relatively close to those holding contradictory views. Notably bigger differences occur among persons who previously visited Germany. In this group almost twice as many peopleesteem Germany as an attractive tourism destination. Higher ratings overlap with the previous responses that emphasised the fact that persons having visited Germany rate the tourism potentials of the country higher. At the same time the results fails to translate into a definitely increased willingness to travel again to Germany. As shown in Table 3 the number of persons declaring such willingness within both the group of all respondents as well as the group of those surveyed who previously visited Germany are on a par with those reluctant to travel to Germany for tourist purposes. Overall, it seems that for such a large country with extensive offers the rating should be higher.

The implications of evaluating the Germany's attractiveness is the rating of selected tourism attractions of the country. The respondents assessed 
the attractiveness of selected places and events compiled on the basis of the answers given in the pilot survey. As revealed by the data detailed in Table 5 the ratings of specific attractions were varied, and certainly they were affected by respondents' individual preferences which resulted in biased views. The focus should be brought to two issues. First, the rating was based on the scale 1-5 implying that the average rating should be 3 . Among responses outlined in the cafeteria only two attractions: Neuschwanstein and Zugspitze scored the average rating significantly below the average 3 which was, to some extent, the result of low recognition of these two names. In other cases the average rating surpassed the value 3 , specific attractions were thus assessed positively. Though it should be stressed that the average rating exceeded 4 . On the whole, the overall rating appears not to be high, thus confirming the previous conclusions. Second, in most cases, the higher ratings were given to specific attractions by persons who already visited Germany which confirms the previous findings.

Table 5. Evaluation of tourist attractions in Germany

\begin{tabular}{|l|l|l|l|l|l|}
\hline Attraction & $\begin{array}{l}\text { Evaluation } \\
\text { (in total) }\end{array}$ & $\begin{array}{l}\text { Evaluation } \\
\text { (those having } \\
\text { visited Ger- } \\
\text { many) }\end{array}$ & Attraction & $\begin{array}{l}\text { Evalua- } \\
\text { tion (in } \\
\text { total) }\end{array}$ & $\begin{array}{l}\text { Evaluation } \\
\text { (those hav- } \\
\text { ing visited } \\
\text { Germany) }\end{array}$ \\
\hline Saxony & 2.98 & 3.16 & Brandenburg Gate & 3.30 & 3.58 \\
\hline Tropical Islands & 3.61 & 3.61 & Berlin & 3.45 & 3.69 \\
\hline Oktoberfest & 3.62 & 3.62 & Neuschwanstein & 2.54 & 2.75 \\
\hline Alps & 4.29 & 4.29 & Bavaria & 3.45 & 3.56 \\
\hline Hamburg & 3.16 & 3.54 & Munich & 3.33 & 3.54 \\
\hline $\begin{array}{l}\text { Beaches at the } \\
\text { North See }\end{array}$ & 3.46 & 3.06 & Zugspitze & 2.54 & 2.65 \\
\hline Frankfurt & 3.03 & 3.32 & & & \\
\hline
\end{tabular}

Source: Own study based on the research conducted

Notice: Respondents evaluated attractiveness in the scale 1-5

Another component crucial for the perception of the tourist attractiveness of the country, and thus its image as a tourism destination are its inhabitants. As far as Poles are concerned, not entirely positive opinions on Germans could have been expected due to historic background. To minimize the probability of the impact of WW2 associations on the results, a purposive sampling took place resulting in the survey of young persons. Nevertheless a fairly negative stereotype of Germans in Poland should be put into spotlight. According to the results presented in Table 6, Germans are wealthy, precise, reserved, nonsmiling and arrogant. Undoubtedly, this is not a perception that has positive implications for development of tourism and encourages to establish direct 
relationships. Such attributes as: hospitability, kindness, openness which seem to be essential in the context of ongoing discussions were indicated by $20 \%$ of respondents. The results received from persons who previously travelled to Germany did not differ significantly from the indications for the whole surveyed group, and they did not demonstrate a more positive picture of Germans.

Table 6. Associations for Germans

\begin{tabular}{|l|c|c|l|c|c|}
\hline Feature & $\begin{array}{l}\text { In dic a ti on } \\
\text { (total) }\end{array}$ & $\begin{array}{l}\text { Indication (per- } \\
\text { sons having vis- } \\
\text { ited Germany) }\end{array}$ & Feature & $\begin{array}{l}\text { Indication } \\
\text { (total) }\end{array}$ & $\begin{array}{l}\text { Indication (per- } \\
\text { sons having vis- } \\
\text { ited Germany) }\end{array}$ \\
\hline Open & $19 \%$ & $19 \%$ & Hospitable & $11 \%$ & $13 \%$ \\
\hline Wealthy & $69 \%$ & $71 \%$ & Honest & $19 \%$ & $29 \%$ \\
\hline Non-smiling & $40 \%$ & $47 \%$ & Precise & $59 \%$ & $69 \%$ \\
\hline $\begin{array}{l}\text { Entertaining, hu- } \\
\text { morous }\end{array}$ & $13 \%$ & $15 \%$ & Aggressive & $24 \%$ & $19 \%$ \\
\hline Kind & $13 \%$ & $19 \%$ & Reserved & $56 \%$ & $50 \%$ \\
\hline Arrogant & $44 \%$ & $40 \%$ & & & \\
\hline
\end{tabular}

Source: Own study based on the research conducted

Notice: Respondents evaluated attractiveness in the scale 1-5

The concluding part of the survey included an inquiry on the readiness to visit Germany as compared to other selected countries across Europe. The question largely referred to the initial question of the survey examining the attractiveness of specific countries (Table 1). As revealed in Table 7 the willingness to travel to Germany for tourist purposes should be evaluated as low, both in the case of all respondents (2.71) as well as persons having previously visited Germany (2.97). In both cases the average rating hovers below 3 and it is substantially lower than for the Mediterranean countries, or countries being traditionally less popular destinations such as: Norway, Great Britain or the Netherlands. Overall, it is worth highlighting that in the initial part the costs related to high prices in the country were indicated as one of the primary barriers to travelling to Germany. Data illustrated in Table 7, to some extent, contradict this assertion because the travelling costs to countries scoring better ratings than Germany certainly are not lower.

Table 7. Evaluation of willingness to travel to selected countries across Europe

\begin{tabular}{|l|l|l|l|l|l|}
\hline Country & Rating & Country & Rating & Country & Rating \\
\hline Italy & 4.75 & France & 4.03 & Lithuania & 2.41 \\
\hline Spain & 4.63 & Slovakia & 2.78 & Holland & 3.18 \\
\hline Russia & 2.64 & Germany & 2.71 & Ukraine & 2.44 \\
\hline Greece & 4.11 & Great Britain & 3.6 & Portugal & 4.16 \\
\hline
\end{tabular}




\begin{tabular}{|l|l|l|l|l|l|}
\hline $\begin{array}{l}\text { Czech Re- } \\
\text { public }\end{array}$ & 2.75 & Norway & 3.36 & $\begin{array}{l}\text { Germany - per- } \\
\text { sons having vis- } \\
\text { ited the country }\end{array}$ & 2.97 \\
\hline
\end{tabular}

Source: Own study based on the research conducted

Notice: Respondents evaluated attractiveness in the scale 1-5

\section{Summary}

Overall it should be emphasized that the country image and its perception are the critical factors driving tourists' decisions on the international travelling. Essentially, the selection of the country is the initial phase of the consumertourist's decision. Therefore, the need to shape its brand on the tourism market should be given importance.

One of the strongest national brands is Germany brand. While being associated with the quality and durability, it provides significant support for products originating from that country. However, according to the hypothesis established, the situation looks different for the tourism market. Basically, this is a market characterized by exceptional peculiarities where consumers' expectations may be other than for physical products. During the diagnostic poll there appeared numerous grounds for adopting the foregoing hypothesis. The respondents relatively poorly assessed the attractiveness of both Germany as well as German cities as compared to other European places leading to a relatively low willingness to travel to Germany. The group surveyed also estimated the selected attractions relatively poorly, and stereotypes and perception of German citizens further deter from visiting the country.

Therefore, the survey exposed the need of changes and enhanced efforts to implement them in the area discussed. Despite the fact that Germany is a major tourism destination for Poles, it may be presumed that majority of travels evidenced in the statistics include short-term travels connected with easy availability of communication or visits at family residing in the country. Accordingly, these are not typical tourist journeys. Essentially, improvement of the Germany image as a tourism destination would definitely trigger the shift in the attitude, and as revealed by the surveys concluded the changes in this regard are likely in the context of ratings given by persons who previously visited Germany. Their ratings are largely more favourable from the perspective of tourism than those given by respondents in total. 


\section{Bibliography}

Dębski M., (2012) 'Brands of tourist areas as an instrument for stimulating development of tourism in Poland', Marketing i Rynek, , no. 5, pp. 28-35

'European Tourism 2013 - Trends and Prospects' (2013), Quarterly Report European Travel Commision, Brussels, Q1;

Fetscherin M. (2010), 'The determinants and measurement of a country brand: The country brand strength index', International Marketing Review, vol. 27, iss. 4;

Hamzaoui-Essoussi L., Merinka D., Bartikowski B., (2011) 'Brand origin and country of manufacture influences on brand equity and the moderating role of brand typicality', Journal of Business Research, vol. 64, iss. 9;

Herz M. C., Diamantopoulos A. (2013), 'Activation of country stereotypes: automaticity, consonance, and impact', Journal of the Academy of Marketing Science, vol. 41, iss. 4, pp. 400 - 417;

Nagashima A (1970). 'A comparison of Japanese and U.S. attitudes toward foreign products', Journal of Marketing, vol. 34 iss.1, pp. 68-74;

Li D.; Ahn J., Zhou R., Wu B., (2009) 'A Study on the influence of country image on purchase intention of Chinese consumers based on Fishbein's model of reasoned action: Focused on USA, Germany, Japan and South Korea', Frontiers of Business Research in China, vol. 3, iss 4, pp. 621 - 646;

Pappu R., Quester P., (2010) 'Country equity: Conceptualization and empirical evidence', International Business Review, vol. 19, iss. 3, pp. 276-291;

Seth P. (2008), Succesful tourism: Fundamentals of tourism, Sterling Publisher, New Delhi;

Skinner H., Kubacki K., Moss G., Chelly D., (2008) 'International marketing in an enlarged European Union: Some insights into cultural heterogeneity in Central Europe', Journal for East European Management Studies, vol. 13, iss. 3, pp. 193-215;

Sipos Ph., Nefzger C., (2011), Country-of-origin Effect and Competitive Advantage. The Role of a Country's Image with Respect to the Positioning Process of International Firms within the Framework of Global Marketing Strategies, GRIN Verlag, Norderstedt;

Verlegh P. (2010), 'Country Image: Why They Influence Consumers', in Go F., Govers R. (ed.) International Place Branding Yearbook: Place Branding In the New Age of Innovation, , Palgrave Macmillan, New York;

Internet sources:

Smith J. (2012), Switzerland Tops Ranking of 25 Best Country Brands [Online] Available: http://www.forbes.com/sites/jacquelynsmith/2012/10/24/switzerlandtops-ranking-of-25-best-country-brands/ [23 Mar. 2014]

Wyjazdy zagraniczne Polaków [Online] Available: http://www.intur.com.pl/statystyka. htm [20 Mar.2014] 